\title{
Goods and Services Associated with a Sandy Coastal Plain in Southeastern Brazil
}

\author{
Mila Letice Sangali Mattos Ferreira ${ }^{1}$ (D), Tamyris Dias de Mello $^{2}$ (D), \\ Henrique Machado Dias \\ ${ }^{1}$ Departamento de Ciências Florestais e da Madeira, Universidade Federal do Espírito Santo - UFES, \\ Jerônimo Monteiro/ES, Brasil \\ ${ }^{2}$ Programa de Pós-graduação em Ciências Florestais, Universidade Federal do Espírito Santo - UFES, \\ Jerônimo Monteiro/ES, Brasil
}

\begin{abstract}
The objective of this study was to identify, characterize and map an area for its different types of direct and indirect use of native vegetation of sandy coastal plains (Restinga) at "Praia das Neves", a district of the municipality of Presidente Kennedy, state of Espírito Santo, Brazil. Data were collected on site using an orthophotomosaic provided by the State Environmental Institute (IEMA) on a 1:35,000 scale, where plant formations of sandy coastal plains were identified and mapped. Six phytophysiognomies were categorized by the following surveying: Halophyte/Creeping-Psamophyte, Open Scrub Palm, Low Closed Thicket, Open Scrub, Non-Flooded Forest and Herbaceous Swamp. Vegetation portions were fragmented due to use for real estate dynamics and cattle raising activity. Among the most prominent and supplied goods are wood exploitation, vegetable products for food and fresh water supply. Furthermore, the services identified are water resource maintenance and ecological functions provided by sandy coastal plain phytophysiognomies.
\end{abstract}

Keywords: phytophysiognomies, remote sensing, restinga, direct and indirect uses. 


\section{INTRODUCTION}

The ways an ecosystem can be used are divided into two large groups: being of use and non-use value. In the first, values are of direct use, where consumer goods are included. In the second, indirect use forms, such as recreation, transportation in the case of waterways, or dams for power supply by hydroelectric plants.

Goods associated with an ecosystem are directly related to use by consumption (direct use), such as the consumption of plant species for therapeutic or food purposes, being a biological approach (Dias et al., 2014; Soares, 2002). When at ecosystem level and not individual organism, the supply is non-consumption or provision of environmental services. These are only possible to be provided by conservation of the entire ecosystem (Dias \& Soares, 2008). Examples of such use are forests for maintaining water sources and nutrient stocks, which vary according to each ecosystem, such as mangrove and sandy coastal plains (Restinga) (Soares, 2002).

Although there are varied concepts of "Restinga" from geomorphological to vegetative definitions (Magnago et al., 2010), this study adopts terrestrial and coastal ecosystems with strong marine influence, varying according to atmospheric and edaphic conditions (Magnago et al., 2012), in addition to intrinsic factors of dynamic vegetation (Scarano, 2009) presented by different plant communities (Giaretta et al., 2013), forming mosaic vegetation (phytophysiognomies) (Magnago et al., 2011), which can be found along the Brazilian coast.

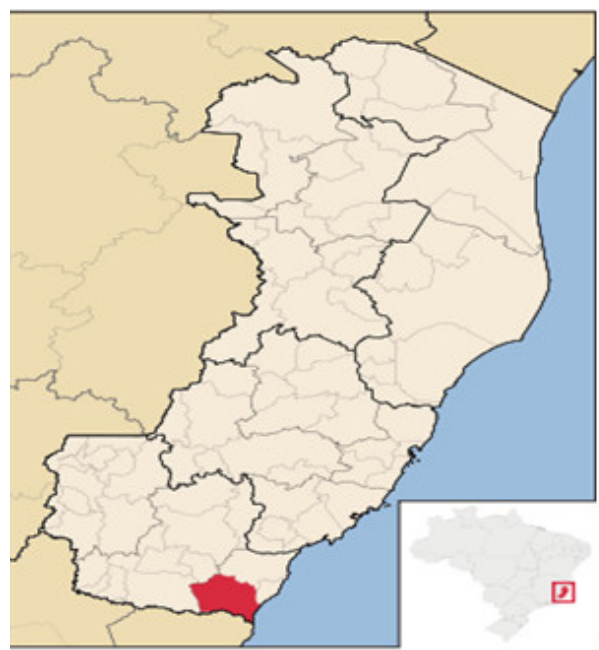

Due to this variability of phytophysiognomies, plant species and associated physical factors of "Restinga" ecosystems (Magnago et al., 2013), together with high biodiversity along the Brazilian coast and different types of uses and services provided by ecosystems (Dias et al., 2014), some "Restinga" fragments are considered by the Ministry of Environment as priorities for conservation, such as "Praia das Neves", in southern state of Espírito Santo (ES).

Thus, objective of this study was to map different "Restinga" phytophysiognomies at "Praia das Neves", Presidente Kennedy-ES, listing associated goods and services on a landscape scale, with the purpose of identifying the variability of phytophysiognomies and classifying them according to a nomenclature system for "Restinga" in southeastern Brazil; to map vegetation remnants and the distribution of these phytophysiognomies along the study area; to identify different types of use by the local population and possible associated impacts; and to list direct and indirect uses associated with each physiognomy.

\section{MATERIAL AND METHODS}

\subsection{Study area and mapping of phytophysiognomies}

The study area is located at "Praia das Neves", a beach district in Presidente Kennedy ( $21^{\circ} 05^{\prime}$ 's; $41^{\circ} 02^{\prime} \mathrm{W}$ ), extreme southern state of Espírito Santo, near "Itabapoana" River on the border with state of Rio de Janeiro (Figure 1).

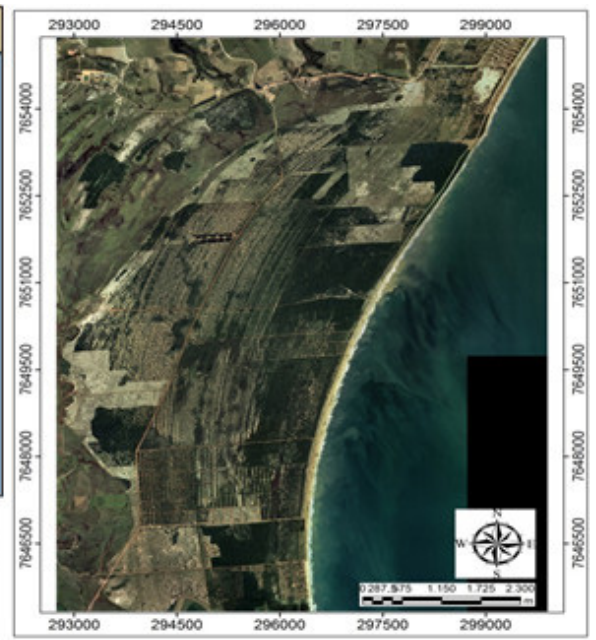

Figure 1. "Praia das Neves" location, Presidente Kennedy, Espírito Santo. 
Land use and occupation mapping was carried out by Orthophotomosaic scanning of 2007 to represent phytophysiognomies and anthropic agents. The map used for the conduction of this study was obtained by local aerial digitized photographs, provided by the State Environment Institute (IEMA), with 1/35,000 scale and spatial resolution of 1 meter.

Screen scanning of features was performed on a standard 1:2,000 scale in ArcGis computational application 10.1 by photointerpretation techniques. The visual image field was enlarged to 1:6000 scale for verification and subsequent scanning (Figure 2).

Photointerpretation was supported by on site recognition of different types of phytophysiognomies based on the establishment of reference points using Garmin 62SCx GPS. The selected area was traveled by roads, aiming to check data (gauging) on sites.

Areas of each community were quantified from mapping different phytophysiognomies using calculator values from a table of attributes of file polygonal vector images, enabling comparing the different sizes of phytophysiognomies found in "Praia das Neves".

\subsection{Classification and analysis of phytophysiognomies using landscape metrics}

Publications available in literature referring to the nomenclature of "Restinga" plant communities from the state of Rio de Janeiro were used for classifying "Restinga" phytophysiognomies in the studied area regarding its physiognomic characteristics, so that whether they are open or closed and have continuous or discontinuous formations (Magnago et al., 2011). Standardization of the classification system in northern state of Rio de Janeiro was performed, since surveys indicate there is high floristic and physiognomical similarity between states (Araujo et al., 2009).

Phytophysiognomies were analyzed based on mapping of vegetation communities in previously established "Restinga" vegetations on site with the purpose of obtaining the relationship of sizes between them, identifying the anthropic agents that have pressured communities through landscape ecology indices.

A minimum area of 10 ha was established for mapped "Restinga" fragments. Based on mapping, vegetation phytophysiognomies obtained within computational environment from ArcMap 10.1 software were computed. The landscape ecology was calculated based on these data using the V-LATE extension (Vector-based Landscape Analysis Tools Extension) and Microsoft Excel spreadsheet was also used.

Archives with different vegetative classes (in shapefile or vector format) were transformed into raster or matrix format, and then metrics. The area of each phytophysiognomy and total "Restinga" area were obtained by size metrics.

In this study, the "Scrub" definition was considered according to Magnago et al. (2011), as any grouping of more than one woody individual with treetop overlap equal to or greater than $50 \mathrm{~cm}$ and separated from other individuals by bare sand or herbaceous vegetation. Vegetation physiognomy is considered to be closed shrub with average height of not more than 4 meters and rectilinear or tortuous stems of small diameter,

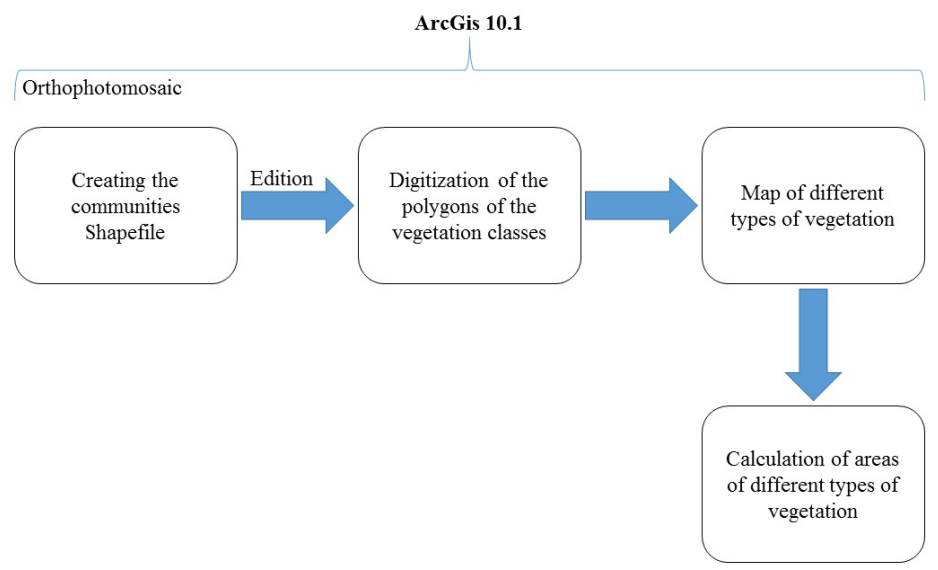

Figure 2. Stages used for mapping different phytophysiognomies. 
forming a "tangle" of individuals, with difficult access (Dias \& Araujo, 2017).

In the present study, landscape is discussed through two approaches: geographic and ecosystemic landscape. Dias \& Soares (2008) defines that the structure and function of the landscape are determined by the way they intertwine integrally and dependent on each other.. Finally, types of direct and indirect uses will vary according to each type of identified landscape (physiognomy).

\subsection{Associated goods and services}

Each phytophysiognomy is listed according to visual and structural vegetation characteristics (Dias \& Soares, 2008), with indicator species also being shown in each one, as well as different uses in the form of goods and services from collecting primary and secondary data surveys. This procedure was performed through the analysis of literature data and field surveys, as well as by crossing these data with information accumulated from each local phytophysiognomy. This information was compared with others available in scientific literature.

The different forms of use of each identified phytophysiognomy were also classified as presented by Soares (2002) in: (i) direct use, referring to goods in a traditional way such as animal and vegetable products; in direct forms of use such as recreation and transport; and (ii) indirect use, represented by the previously mentioned environmental services.

\section{RESULTS AND DISCUSSION}

Through analyses made in "Praia das Neves", it was possible to recognize six different "Restinga" phytophysiognomies distributed in its coastal zone: Halophyte/Creeping-Psamophyte, Open Scrub Palm, Low Closed Thicket, Open Scrub, Non-Flooded Forest and Herbaceous Swamp, as well as delimited areas that suffer some type of anthropic intervention (Figure 3 ). Categories of goods and services were also identified for each phytophysiognomy and their use by population.

a) Halophyte/Creeping-Psamophyte: vegetation closest to the beach line, being affected by the highest spring tides. These two phytophysiognomies are very difficult to distinguish because there is no clear zoning between them due to intense erosive process, so in this study, they were only treated as phytophysiognomy.

This physiognomy in "Praia das Neves" occurs in a variable width of 50-60 meters, and may be higher or lower depending on the location. It has high vegetation cover, being dominated by herbaceous (rhizomatous and crawling) specimens that have long and prostrate stems, also acting as a barrier against sand movement. For this reason, the vegetation is very impacted due to tourist activities mainly in the summer months by excessive movement of beachgoers that also leave solid waste or are brought by the tide.

b) Open Scrub Palm: in the state of Espírito Santo, this phytophysiognomy is designated as Palmae Formation (Magnago et al., 2011), being visually dominated by Allagoptera arenaria, a species popularly known as "Guriri" or "Coquinho-da-praia", and has been undergoing an excessive degradation process, as well as Halophyte/Creeping-Psamophyte, also by occurring close to roads by the seaside;

c) Low Closed Thicket: this vegetation is dense and woody in places that suffer minor anthropogenic actions, with presence of spiny species difficult to

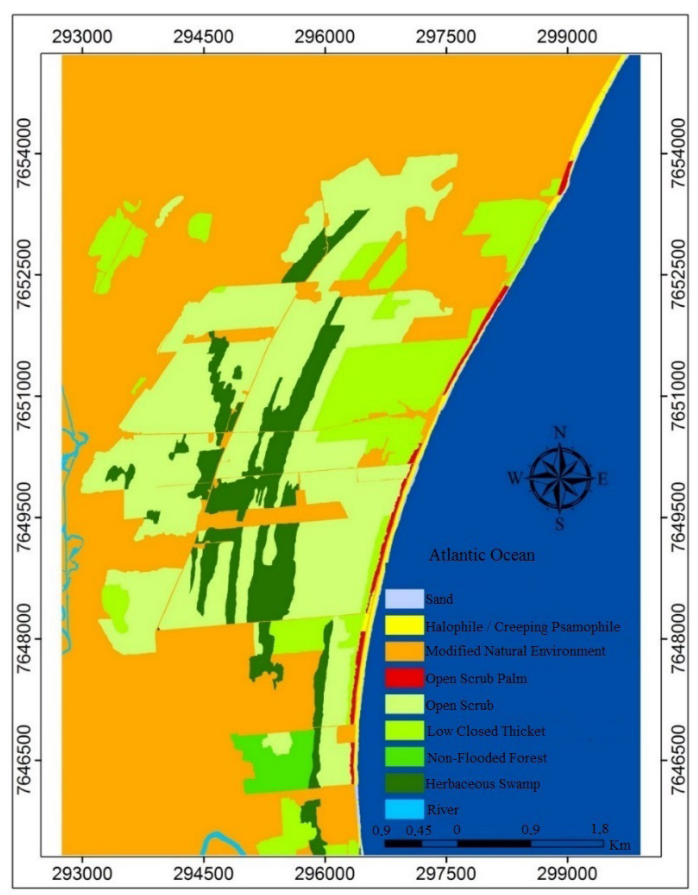

Figure 3. Map of different phytophysiognomies obtained through digital aerial photographs and photointerpretation of the study region. 
penetrate. Height reaches about 4 meters with no spaces intercalated by bare areas. It is similar to Myrtaceae Closed Shrub described for the state of Rio de Janeiro (Dias \& Araujo, 2017). There is the possibility of getting very close to this physiognomy in "Praia das Neves" because it is cut by roads in certain places. As a consequence, there is evidence of specimen removal for firewood and home decoration;

d) Open Scrub: vegetation consisting of dense scrub spaced or not from each other, and which is presented in various sizes intercalated by sandy strings where vegetation is sparse. The crowns of larger trees usually extend to the soil surface. The physiognomically predominant species in the area is Clusia hilariana. In this study, the area is delimited by Low Closed Thicket and in some points intercalates with Herbaceous Swamp.

Magnago et al. (2011) denominates this phytophysiognomy as Shrubby Open Non-Flooded. Scarano (2009) reported that species of this environment are adapted to tolerate high temperatures; high salinity, lack of nutrients and water deficits that other species would not tolerate.

As occurs in "Praia das Neves", mainly due to the ease of access, Dias \& Soares (2008) found the same pattern for "Restinga" vegetation of Caravelas, Bahia, showing strong impact due to wood cutting for firewood and house building, in addition to exploitation of orchids for ornamentation.

e) Non-Flooded Forest: this phytophysiognomy in the state of Espirito Santo was defined by Magnago et al. (2011) as Non-Flooded Forest. In "Praia das Neves", there is a small remnant of this type of vegetation, so it is very susceptible to anthropic action. Due to the difficulty in accessing the interior of the forest, it is possible to verify a certain degree of conservation, with the substrate of this vegetation having abundance of litter. The upper stratum in the interior of the forest reaches between 15 and 20 meters in height, the medium stratum is dense, with poor sub-forest in herbaceous species;

f) Herbaceous Swamp: also defined as Flooded Herbaceous (Magnago et al., 2011), this vegetation suffers permanent soil flooding, being greater in the rainy season where a superficial outcrop is verified from the water table. In this area, the coastal swamp occurs at irregular site, mostly surrounded by the shrub.

Dias \& Soares (2008) affirms that this phytophysiognomy tends to occur between sandy cords in different degrees of density, coverage and composition. The characteristic species of this environment is commonly called "taboa" (Typha domingensis), ranging from 2 to 3 meters in height. In adition to being entirely edible (when new), it also plays an important biological role as refuge for species of birds and small rodents.

For "Restinga" phytophysiognomies in "Praia das Neves", it was possible to verify physiognomic classes found in the area through the landscape, as well as their respective sizes in hectares of natural remnants and with anthropic modification (Table 1).

\subsection{Goods and services associated with Restinga in Praia das Neves}

Regardless of existence or not of effects from anthropic influence on the complexity of "Restinga" environments, it was observed that there is a relationship between the different "Restinga" physiognomies and goods and services that they offer, as well as their use by human populations. Table 2 presents all uses and functions identified for different "Restinga" physiognomies in "Praia das Neves". A set of goods (direct uses) and services (indirect uses) associated to functions in landscape scale are described by Dias \& Soares (2008) and Soares (2002).

The complexity of "Restinga" ecosystems can vary according to anthropic pressures such as selective cutting, forest fires, cattle ranching, sand extraction and unorganized/unmonitored recreational use. The use by the population of plant

Table 1. Phytophysionomic classes found in "Praia das Neves”, Presidente Kennedy (ES), with total area of each class (ha) and respective percentage.

\begin{tabular}{lrr}
\multicolumn{1}{c}{ Classes } & $\begin{array}{c}\text { Total area } \\
\text { (ha) }\end{array}$ & \% \\
\hline Halophyte/Creeping-Psamophyte & 37.01 & 0.78 \\
\hline Open Scrub Palm & 25.32 & 0.54 \\
\hline Low Closed Thicket & 425.01 & 8.99 \\
\hline Open Scrub & $1,085.77$ & 22.97 \\
\hline Non-Flooded Forest & 53.75 & 1.14 \\
Herbaceous Swamp & 311.18 & 6.58 \\
Modified Natural Landscape & $2,787.90$ & 58.99 \\
Total & $\mathbf{4 , 7 2 5 . 9 4}$ & $\mathbf{1 0 0}$ \\
\hline
\end{tabular}


Table 2. Categories of uses and services for "Restinga" physiognomies identified in "Praia das Neves", Presidente Kennedy (ES).

\begin{tabular}{|c|c|c|c|c|c|c|c|}
\hline \multirow[b]{2}{*}{$x^{2}$} & \multirow{2}{*}{ Uses and Services } & \multicolumn{6}{|c|}{ Physiognomies } \\
\hline & & 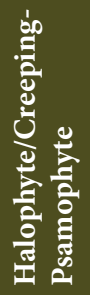 & 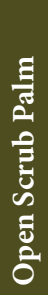 & 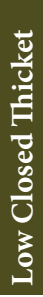 & 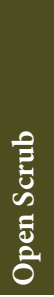 & 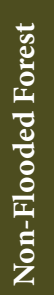 & 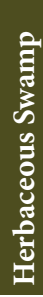 \\
\hline \multirow{7}{*}{$\begin{array}{l}\text { Functions / } \\
\text { Services in } \\
\text { landscape scale } \\
\text { (services / } \\
\text { indirect uses) }\end{array}$} & Sediment protection and stabilization & $\mathrm{X}$ & $\mathrm{X}$ & $\mathrm{X}$ & $\mathrm{X}$ & $\mathrm{X}$ & $\mathrm{X}$ \\
\hline & Maintenance of biological diversity & $\mathrm{X}$ & $\mathrm{X}$ & $\mathrm{X}$ & $\mathrm{X}$ & $\mathrm{X}$ & $\mathrm{X}$ \\
\hline & Landing for migratory birds & & & & & & $\mathrm{X}$ \\
\hline & Maintenance of fresh water tanks & & $\mathrm{X}$ & $\mathrm{X}$ & $\mathrm{X}$ & $\mathrm{X}$ & $\mathrm{X}$ \\
\hline & Recharge of aquifers & & $\mathrm{X}$ & $\mathrm{X}$ & $\mathrm{X}$ & $\mathrm{X}$ & $\mathrm{X}$ \\
\hline & Freshwater source for rivers & & & & $\mathrm{X}$ & & $\mathrm{X}$ \\
\hline & Maintenance of ecological functions & $\mathrm{X}$ & $\mathrm{X}$ & $\mathrm{X}$ & $\mathrm{X}$ & $\mathrm{X}$ & $\mathrm{X}$ \\
\hline \multirow{7}{*}{$\begin{array}{l}\text { Uses by urban } \\
\text { communities } \\
\text { (goods / direct } \\
\text { uses) }\end{array}$} & Use of plant products for food & & $\mathrm{X}$ & $\mathrm{X}$ & $\mathrm{X}$ & $\mathrm{X}$ & $\mathrm{X}$ \\
\hline & Use of plant products for medicinal purposes & & & $\mathrm{X}$ & $\mathrm{X}$ & $\mathrm{X}$ & \\
\hline & $\begin{array}{l}\text { Wood source for firewood, construction of fishing } \\
\text { artifacts and residences }\end{array}$ & & & $\mathrm{X}$ & $\mathrm{X}$ & $\mathrm{X}$ & \\
\hline & Hunting and fishing & & & $\mathrm{X}$ & & $\mathrm{X}$ & $\mathrm{X}$ \\
\hline & Use of plant products for various purposes & & $\mathrm{X}$ & $\mathrm{X}$ & $\mathrm{X}$ & $\mathrm{X}$ & \\
\hline & Source of ornamental plant species & & $\mathrm{X}$ & $\mathrm{X}$ & $\mathrm{X}$ & $\mathrm{X}$ & \\
\hline & $\begin{array}{l}\text { Maintenance of water source for residential supply } \\
\text { (artesian wells) }\end{array}$ & & & & & & $\mathrm{X}$ \\
\hline \multirow{6}{*}{$\begin{array}{l}\text { Use of space } \\
\text { with natural } \\
\text { system } \\
\text { replacement }\end{array}$} & Real estate speculation & & $\mathrm{X}$ & $\mathrm{X}$ & $\mathrm{X}$ & & \\
\hline & Livestock & & $\mathrm{X}$ & & $\mathrm{X}$ & & \\
\hline & Trash dump site & & & & $\mathrm{X}$ & & \\
\hline & Residential allotment & & & $\mathrm{X}$ & $\mathrm{X}$ & & \\
\hline & Sand extraction & & & & $\mathrm{X}$ & & \\
\hline & Casuarina equestifolia monoculture & & $\mathrm{X}$ & $\mathrm{X}$ & & & \\
\hline
\end{tabular}

products for food can be observed, except for the Halophyte/Creeping-Psamophytephysiognomy, for being an area near the beach line and having strong influence of sea waves. The use of vegetation for medicinal purposes is also verified, found in Open Scrub Palm, Low Closed Thicket and Open Scrubphysiognomies.

Herbaceous swamp stands out as a source of fresh water for residential supply through artesian wells, and therefore it is of fundamental importance to preserve this "Restinga" ecosystem to maintain stable water resources. In this context and demonstrating the importance of maintaining these environments for the equilibrium of associated ecosystems, Chaves et al. (2009) described that all the systems in the "Abrolhos" marine bank (southern Bahia/northern Espírito Santo) are closely related and interconnected. Thus, the reef ecosystem is directly associated to mangrove ecosystem and "Restinga" vegetation in terms of turbidity control of coastal waters, flow of organic materials and nutrients and maintenance of young reef fish species.

Granek et al. (2010) discuss the importance of groundwater flow for maintenance of mangrove forests, either through rivers in ecosystems or by water outcropping, both upstream of the river and along its courses, demonstrating the importance of preserving "Restinga" terrestrial vegetation cover to maintain the permeable substrate, allowing rainwater to feed underground aquifers.

Issues related to conservation of natural resources in the "Praia das Neves" region are strategic for the survival of communities in these regions, both to guarantee the integrity of systems from which these populations extract their resources and for being instrumental in 
maintaining the availability of fresh water for human consumption and activities related to agriculture and livestock (Chaves et al., 2009).

In "Praia das Neves", the removal of woody plants (trees and shrubs) to supply wood for consumption in homes is the main direct impact for Non-Flooded Forest, Open Scrub and Low Closed Thicket communities. In the state of Rio de Janeiro, the characteristics of "Restinga" forests are the most affected due to tree removal for firewood production (Sá \& Araujo, 2009). The same is observed in Caravelas-BA due to the presence of clandestine charcoal (Dias \& Soares, 2008).

Pereira (2007) reported that the "Restinga" vegetation in the state of Espírito Santo has historically been substituted by subsistence monocultures, but currently they are being used for sand extraction, real estate speculation and wood cutting for fuel and furniture. In "Praia das Neves", there is the visually perceptible removal of Open Scrub and Low Closed Thicket phytophysiognomies for residential and commercial subdivision.

Open Scrub Palm and Low Closed Thicket phytophysiognomies were suppressed in the past for forest cultivation of exotic species Casuarina equestifolia, known as Australian Pine, which once established, causes covering and strongly competes with native vegetation, as verified on site and in other "Restinga" areas in southeastern Brazil. The Open Scrub physiognomy has much of its area modified for housing construction, agricultural farming, as well as residential subdivisions and roads. Nevertheless, Open Scrub physiognomy composes the greater landscape in the study area when compared to other phytophysiognomies.

In addition to sand extraction, another problem is the illegal dumping of trash and rubble, which can contaminate permeable sandy soils of this vegetation type, as well as groundwater and underground reservoirs. Large number of abandoned residences can be observed in "Praia das Neves", which is linked to strong degradation levels because it collaborates to impoverish the soil with consequent abandonment of the area, favoring an uncontrolled process of population growth in the urban center.

It was observed that the local population of "Praia das Neves" makes direct and/or indirect use of products and services provided by the "Restinga" ecosystem. Indirect uses are linked to the entire ecosystem and their connection to external environment varies according to the integrity of each physiognomy (Fonseca-Kruel et al., 2009; Dias \& Soares, 2008). In this context, the importance of conserving each of these environments is clearly demonstrated for the balance of the entire ecosystem.

It possible to observe that most of the area selected for study has undergone some type of human intervention for housing, roads, water well construction, diverse soil uses, among others, where the modified natural landscape represents the highest value (Orofino et al., 2017). This process may result in immediate extinction of some species, and according to Tabarelli et al. (2010), expose surviving organisms to the effects of the altered environment over time.

For this reason, we believe that sustainable management of "Restinga" phytophysiognomies can be used as one of the forms of coastal management, approaching it from an ecosystem landscape scale through a geographical landscape that has as the final product the interaction between social, cultural and environmental aspects.

\section{CONCLUSIONS}

1)Aerial photographic mapping allowed determining, mapping and classifying six "Restinga" physiognomies in "Praia das Neves";

2) Exploited goods vary according to such phytophysionomies and services are linked to entire ecosystems, and its influence on the landscape interacts with all adjacent systems;

3) The major form of identifying degradation was complete or partial removal of vegetation for livestock activities and real estate speculation;

4) There is need for rational use of physiognomies in order to guarantee the conservation of "Restinga" ecosystems, so that these areas continue to provide necessary ecosystem services.

\section{ACKNOWLEDGEMENTS}

This study was partly financed by the "Conselho Nacional de Desenvolvimento Científico e Tecnológico" $(\mathrm{CNPq})$ and the "Fundação de Amparo à Pesquisa e Inovação do Espírito Santo" (FAPES) - Edital FAPES/CNPq - PPP n ${ }^{\circ}$. 02/2011 for funding this research. 


\section{SUBMISSION STATUS}

Received: 29 oct., 2018

Accepted: 4 dec., 2018

\section{CORRESPONDENCE TO}

\section{Henrique Machado Dias}

Departamento de Ciências Florestais e da

Madeira, Universidade Federal do Espirito

Santo - UFES, Av. Gov. Carlos Lindemberg, 316,

Nedtec, CEP 29550-000, Jerônimo Monteiro, ES,

Brasil

e-mail: henridias@yahoo.com.br

\section{REFERENCES}

Araujo DSD, Sá CFC, Fontella-Pereira J, Garcia DS, Ferreira MV, Paixão RJ et al. Área de Proteção Ambiental de Massambaba, Rio de Janeiro: caracterização fitofisionômica e florística. Rodriguésia 2009; 60(1): 67-96. http://dx.doi. org/10.1590/2175-7860200960104.

Chaves FO, Soares MLG, Estrada GCD, Cavalcanti VF. Maintenance of mangrove forest through the conservation of coastal ecosystems. Journal of Coastal Research 2009; 56: 395-399.

Dias HM, Araujo DSD. Estrutura do estrato lenhoso de uma comunidade arbustiva fechada sobre cordão arenoso na restinga da Marambaia - RJ. Ciência Florestal 2017; 27(4): 1129-1142. http://dx.doi.org/10.5902/1980509830290.

Dias HM, Soares MLG, Neffa E. Espécies florestais de restingas como potenciais instrumentos para gestão costeira e tecnologia social em Caravelas, Bahia (Brasil). Ciência Florestal 2014; 24(3): 727-740. http://dx.doi. org/10.5902/1980509815732.

Dias HM, Soares MLG. As fitofisionomias das restingas do município de Caravelas (Bahia-Brasil) e os bens e serviços associados. Boletim Técnico-Científico do CEPENE 2008; 16(1): 59-74.

Fonseca-Kruel VS, Araujo DSD, Sá CFC, Peixoto AL. Quantitative ethno botany of a restinga forest fragment in Rio de Janeiro, Brazil. Rodriguésia 2009; 60(1): 187-202. http://dx.doi.org/10.1590/2175-7860200960110.

Giaretta A, Menezes LFT, Pereira OJ. Structure and floristic pattern of a coastal dunes in southeastern Brazil. Acta Botanica Brasílica 2013; 27(1): 87-107. http://dx.doi. org/10.1590/S0102-33062013000100011.
Granek EF, Polasky S, Kappel CV, Reed DJ, Stoms DM, Koch EW et al. Ecosystem services as a common language for coastal ecosystem-based management. Conservation Biology 2010; 24(1): 207-216. http://dx.doi.org/10.1111/ j.1523-1739.2009.01355.x. PMid:19906066.

Magnago LFS, Martins SV, Pereira OJ. Heterogeneidade florística das fitocenoses de restingas nos estados do Rio de Janeiro e Espírito Santo, Brasil. Revista Árvore 2011; 35(2): 245-254. http://dx.doi.org/10.1590/S010067622011000200009 .

Magnago LFS, Martins SV, Schaefer CEGR, Neri AV. Gradiente fitofisionômico-edáfico em formações florestais de Restinga no Sudeste do Brasil. Acta Botanica Brasílica 2010; 24(3): 734-746. http://dx.doi.org/10.1590/S010233062010000300017 .

Magnago LFS, Martins SV, Schaefer CEGR, Neri AV. Restinga forests of Brazilian coast: richness and abundance of tree species on different soils. Anais da Academia Brasileira de Ciências 2012; 84(3): 807-822. http://dx.doi.org/10.1590/ S0001-37652012000300023. PMid:22886165.

Magnago LFS, Martins SV, Schaefer CEGR, Neri AV. Structure and diversity of restingas along flood gradient in southeastern Brazil. Acta Botanica Brasílica 2013; 27(4): 801809. http://dx.doi.org/10.1590/S0102-33062013000400020.

Orofino GG, Roque TV, Fonseca-Kruel VS, Peroni N, Hanazaki N. Local knowledge about dugout canoes reveals connections between forests and fisheries. Environment, Development and Sustainability 2017; 19: 1-21.

Pereira OJ. Diversidade e conservação das restingas do Espírito Santo. In: Menezes LFT, Pires FR, Pereira OJ, editors. Ecossistemas costeiros do Espírito Santo. Vitória: INCAPER; 2007.

Sá CFC, Araujo DSD. Estrutura e florística de uma floresta de restinga em Ipitangas, Saquarema, Rio de Janeiro, Brasil. Rodriguésia 2009; 60(1): 147-170. http://dx.doi. org/10.1590/2175-7860200960108.

Scarano FR. Plant communities at the periphery of the Atlantic Rain Forest: rare species bias and its risks for conservation. Biological Conservation 2009; 142(6): 12011208. http://dx.doi.org/10.1016/j.biocon.2009.02.027.

Soares MLG. Ética e conservação da diversidade biológica. In: Bartholo R, Ribeiro H, Bittencourt JN, editors. Ética e sustentabilidade. Rio de Janeiro: Engenho e Arte; 2002.

Tabarelli M, Aguiar AV, Ribeiro MC, Metzger JP, Peres CA. Prospects for biodiversity conservation in the Atlantic Forest: lessons from aging human-modified landscapes. Biological Conservation 2010; 143(10): 2328-2340. http:// dx.doi.org/10.1016/j.biocon.2010.02.005. 